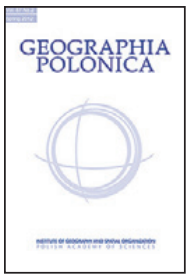

\title{
18TH-20TH CENTURY FLOOD-INDUCED CHANGES IN THE LANDSCAPES OF THE MAŁA WISŁA VALLEY WITHIN THE OŚWIĘCIMSKA BASIN
}

\section{Stanisław W. Czaja}

\author{
University of Silesia \\ Faculty of Earth Sciences \\ Będzińska 60, 41-200 Sosnowiec: Poland \\ e-mail address: stanislaw.czaja@us.edu.pl
}

\begin{abstract}
Shaping of the Mała Wisła ('Little Vistula') Valley allowed economic use to be made of it by the early Middle Ages. At first, this took the form of the constructing of many mill streams, but then the system of fish ponds characteristic of the Valley landscape to this day was also put in place (in the 16th-17th centuries). However, the numerous floods affecting the Valley down the centuries regularly devastated the ponds, as well as filling in or changing the courses of the mill streams. Archive records, sketches and topographic maps all show that the receding of floodwaters was followed by the rebuilding of ponds albeit mostly with shapes, sizes and layouts of embankments different from those that had been present before. This therefore brought about significant changes in the landscape of the Valley. By the end of the 19th century, floods had produced very marked changes in the landscape of the Valley under study. In contrast, floods do not now bring about permanent changes in the Valley because the construction of the Goczałkowice Reservoir led to a lowering in the level of episodes of peak high water.
\end{abstract}

\section{Key words}

Poland • Mała Wisła Valley • changes in landscapes • human impact • floods

\section{Introduction}

There can be no doubt that the Mała Wisła ('Little Vistula') Valley began to come under management at the very dawn of the existence of the Polish state. At that time, people were seeking to locate - and adapt as necessary - those places suitable for more permanent settlement, also bringing the Valley into cultivation, while the river itself served as a venue for the catching of fish and for navigation. The shaping of the section of the Vistula Valley in question was also influenced by the construction of many branches off the main channel, along which mills, cloth-washing facilities and sawmills were set up. New ways of making use of the area also emerged in the 17th century, as the system of fishponds still characterising the Valley landscape to this day was first put in place.

Up until the mid 18th century, this area was dominated by primaeval riparian forest that continued to cover as much as $40 \%$ of its area (Szweda 2008). Wet meadows in turn constituted $30 \%$, arable land just 15\%. The fishponds already referred to as a major landscape element covered almost $14 \%$ of the area (Wieland 1736; Czaki 1760; Fig. 1 and 2).

From the mid 19th century onwards, work began on the melioration of wet meadows, with a view to 


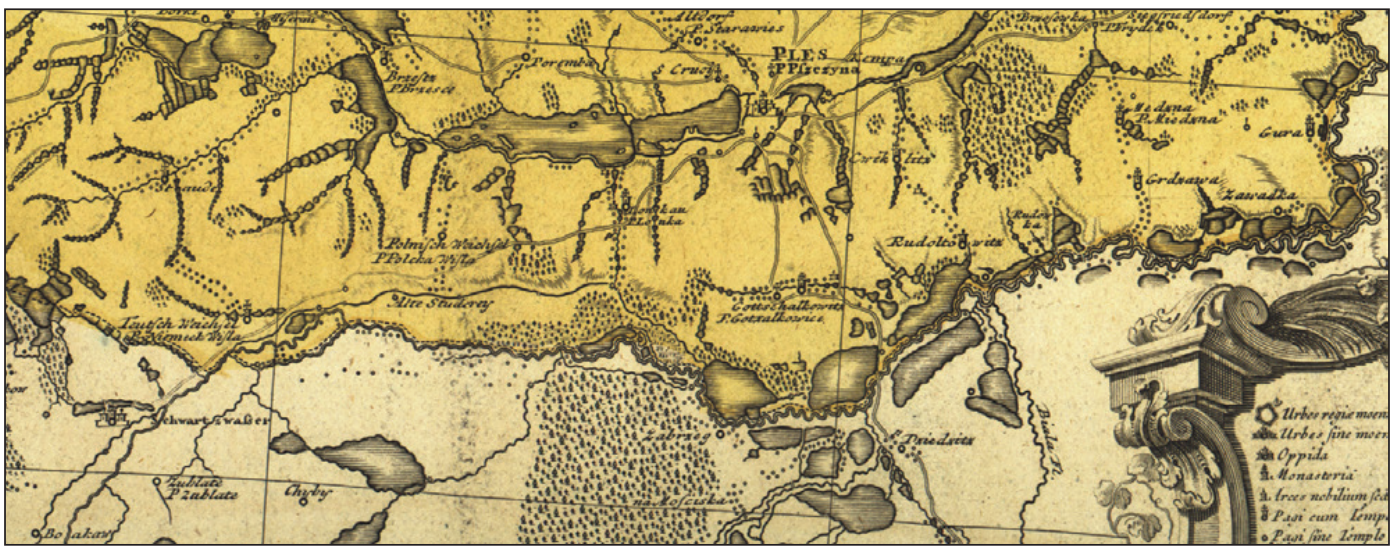

Figure 1. The Mała Wisła Valley between Strumien and the confluence with the Biała on the J.W. Wieland map dating from 1736.

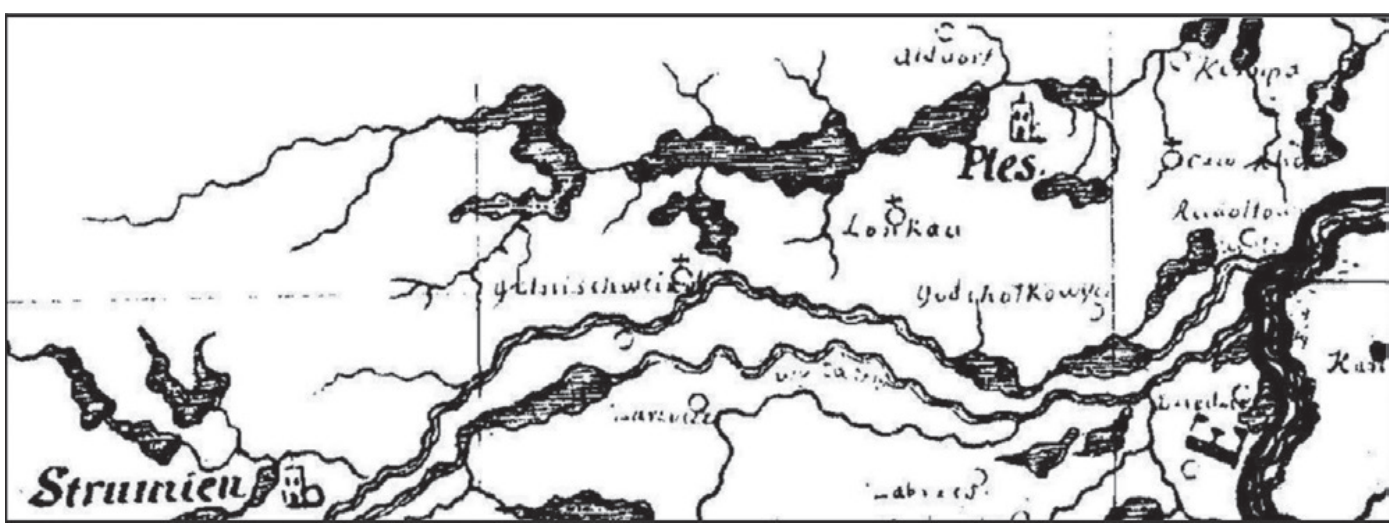

Figure 2. The Mała Wisła Valley between Strumień and the confluence with the Biała on the F.F. Czaki map dating from ca. 1760.

the land being used in the cultivation of cereals; while forests were felled both within the Vistula Valley and in the foothills area of the river basin. The consequence of this activity was a marked increase in the area of cultivated fields, which were occupying almost $45 \%$ of the Valley area by the first years of the 20th century. Alongside economic activity, flooding (especially extreme flooding) played an important role in shaping the Mała Wisła Valley, being responsible for the destruction of the embankments around fishponds, as well as the filling-in of river channels, or the modification of their courses. Archival references, as well as topographical maps and sketches, make it clear that ponds were mostly reinstated following flooding, though obviously it was normal for them to be of shapes and sizes different from those present before.

Today, floods are not bringing about more permanent change in the landscape of the Mała
Wisła Valley - primarily because the consequences of peak high-water events have been limited through the installation of such hydrotechnical installations as weirs, spurs and dams. Also of major significance has been the straightening and regulation of river channels, as well as the construction of floodbanks along them. Such work began as early as in the mid 19th century, but it was only in the 1920s that it took in the part of the Valley described here. However, a fundamental influence in limiting the threat of flooding was exerted by the construction - as relatively recently as in the 1950s - of the retention reservoir at Goczałkowice. From that time onward, it has only been the truly major flood disasters (such as those of 1997 and 2010) that have proved capable of causing the entire floor of the Valley to flood, with consequent channel modification of a more durable nature taking place. 
The aim of the work described here has been to recreate the changes taking place in the landscape of the Mała Wisła Valley in the stretch extending from Strumien to the confluence with the River Biała. From the 16th century onwards, this part of the Valley was put to use in the rearing of fish for food. Thus, as early as in the mid 18th century, the landscape here had come to be dominated by a number of large ponds accounting for up to $20 \%$ of the entire area. It was very typical for large flood events to result in changes in both the distributions and sizes of these fishponds. Following destruction of the embankments, many ponds were converted into cultivated fields, while others were re-established, albeit with different shapes and areas from before.

The method applied in the work involved analysis of records and large-scale topographic maps, of which the oldest examples derive from the mid 18th century. To eliminate error arising out of the inaccuracy of old maps, these were compared in terms of distances and azimuths with contemporary maps and aerial photographs.

\section{Shaping of the landscape and the history of management in the Mała Wisła Valley}

The analysed length of Valley of the Mała Wisła is in the western part of the Oświęcim Basin, extending west from Strumień as far as the confluence point with the River Biała in the eastern part of the Basin. This is thus a belt around $22 \mathrm{~km}$ in length, as well as $4-10 \mathrm{~km}$ in width. To the north, it is confined by the undulating Pszczyna Plateau, reaching maximum elevations of 260-275 m a.s.l., or just $15-25 \mathrm{~m}$ above the floor of the Vistula Valley. To the south, the Valley running north-south is confined by the Międzyrzec Plateau of maximum elevation 280-300 m a.s.l., or 35-70 m above the floor of the Valley.

The landforms of this part of the Vistula Valley are associated with the Ice Age. Specifically, at the time of Poland's San Glaciation, the ice sheet resting against the threshold of the Beskid range gave rise to a valley between the area of today's Zator and Kraków, this making it possible for meltwaters to flow out from the Oświęcim Basin into the Sandomierz Basin. A similar situation applied at the time of the Oder Glaciation, during which the ice sheet reached as far as the Rybnica Plateau, with a river carrying meltwaters eastwards constructing outwash plains and sandy terraces in the part of the Vistula Valley under consideration. Finally, the last (Vistulian) Glaciation found the Mała Wisła Valley within the range of impact of a periglacial climate. At that time, there was strong downcutting erosion by the Vistula, this ensuring the establishment of a low river terrace of that age. Denudation processes in the conditions of a cold climate led to severe erosion of slopes and to enhanced accumulation in river valleys (Węcławik 1991).

Work carried out by Starkel (2001) shows how the river flowing within the Oświęcim Basin during the Holocene was not overloaded with material, a meandering channel therefore dominating. However, the hydrological regime characterising these rivers was subject to dynamic change, as is attested to by 'abandoned' channels of various origins, as well as the alluvial covers laid down side by side and pointing to the existence of phases of flooding of different frequency, in the course of which changes in the channel took place.

An activation of the aggradation of material in valley bottoms and at the foot of slopes was also brought about by human activity as early as in $\mathrm{Ne}$ olithic times (Starkel 1991). In turn, the 17th and 18th century circumstances of the 'Little Ice Age' combined with the felling of forests in the foothills and higher parts of the Beskids to generate flood events of increased magnitude and frequency.

The Mała Wisła Valley was associated widely with the presence of braided channels. This reflected the washing of large amounts of soil off slopes, and the attendant loading of river waters with rocky debris. It was at this time that the final (current) shape was assumed by the uppermost layers of plain, i.e. the so-called 'rendzina' terrace. This terrace currently serves as the floodplain, and is indeed inundated at times of peak high water.

An important element to the landscape of the Mała Wisła Valley, alongside the formations creating its substratum and the relief of the land, is the vegetation cover. The latter's current state reflects a changing climate and ongoing pedogenetic processes.

The plant cover that has taken shape in more recent times has obviously been very much influenced by human economic activities. Following the retreat of the ice sheets from Central Europe, a great 'rebounding' of plants into the newly-open areas began, a major conduit for this being the 
adjacent valley of the River Oder, which flows up from the south. In the boreal period, broadleaved trees and shrubs like birch, lime, oak, elm and hazel encroached upon the Valley, while the period of the climatic optimum brought in beech, yew and fir, and later hornbeam and ash (Michalik 1991).

The area of the Mała Wisła Valley is today characterised by a plant cover of rather limited diversity, though the terrace structure of the Valley influences the spatial distribution of the plant communities that are present here (Czylok et al. 1997). Once widespread in swampy areas and on the low terraces along the Vistula was alder carr, as well as patches of poplar/willow forest. Today, neither of these types is found here more than sporadically. The Valley proper primarily supports monocultures of Scots pine, though an admixture of spruce and downy birch is not unknown. In the main, the stands are still young. Broadleaved or mixed/broadleaved forests are characteristic of very dry land, most often on more-elevated terraces. In turn, swampy depressions with no outflow along the Mała Wisła Valley support coniferous forest of both the fresh and marshy variants. The aquatic and marshland vegetation in this part of the Valley has also in fact undergone a major (in some cases dramatic) transformation, thanks to the regulation of the main river channel and near-confluence sections of tributaries. Change in the plant communities in question was also brought about by the filling-in of fishponds still put to use not far into the past. The communities of permanent grasslands (meadows and pastures), which occupy more than 30\% of the described section of the Mała Wisła Valley, are mostly put to economic use, and it is the meadows receiving some fertiliser and made subject to regular cutting that have a more diverse floristic composition (Michalik 1991).

The Vistula in the section under study is a typical lowland river, in that the gradient is very slight and there are numerous bends and meanders. The part of the Valley immediately adjacent to the channel is the floodplain area, which is $2-4 \mathrm{~km}$ wide in the stretch under consideration. This a flat, marshy area supporting wet-meadow vegetation. As has already been noted, the Pleistocene period saw the Oder lay down at least three terrace-levels that were cut into until recent times by tributaries of the main river, or else overlain by their alluvial fans. These areas are characterised by conditions far more favourable to agriculture.

\section{The development of settlement}

The beginnings of settlement in the Vistula Valley stretch back to the 13th-15th centuries, as is attested to by references to the locating of towns and villages that are to be found in a large number of different historical sources. The flat and broad valley bottom is a habitat for meadows and pastures. These were cut across by numerous ditches and millstreams, with the Vistula flowing via two separate channels from the mid 18th-century onwards.

Of major significance to the development of settlement and agriculture was the fact that it was only in the late Middle Ages that farmers first mastered the technique of cultivating soils that were very fertile, but also wet and heavy. Analysis of historical sources plus archival sketches and maps makes it clear that many villages and hamlets were built on more elevated terraces of the Vistula, as well as on slopes of river terraces where these were not too steep.

Places in which the Valley grows broader also have wider Pleistocene terrace landforms incised by the valleys of numerous rivers and brooks flowing down from the Carpathians, as well as the Rybnik and Golejów Plateaus. Their valleys, as well as the only slightly-inclined slopes of plateaus, support long 'chain villages' orientated at right angles to the course of the Vistula channel (Fig. 3). These villages may often stretch for several kilometres, while their extent within the Vistula Valley is most often limited by the river flood zone designated by the edges of the terraces. The place-names involved here are Goczałkowice, Wisła Wielka, Wisła Mała and Łaka (Fig. 3). The extents of these villages within the Vistula Valley also attest to the forest cover once present here. In those areas in which the Valley is not too wide, the villages and hamlets only occupy the narrow zones of tributaries of the Vistula, and are not inclined to encroach on to the river terraces. The chain villages are characteristic for the Oświęcim Basin and 'Moravian Gate' area, as well as for the section of the Oder extending as far as Racibórz and running in a gorge.

Today, the Vistula channel is regulated and embanked, since the years from the end of the 19th century brought a great deal of regulatory work, this most especially seeking to dig through the necks of meanders. However, river bends remain very visible elements of the Valley morphology, while depressions they leave may fill with water to 


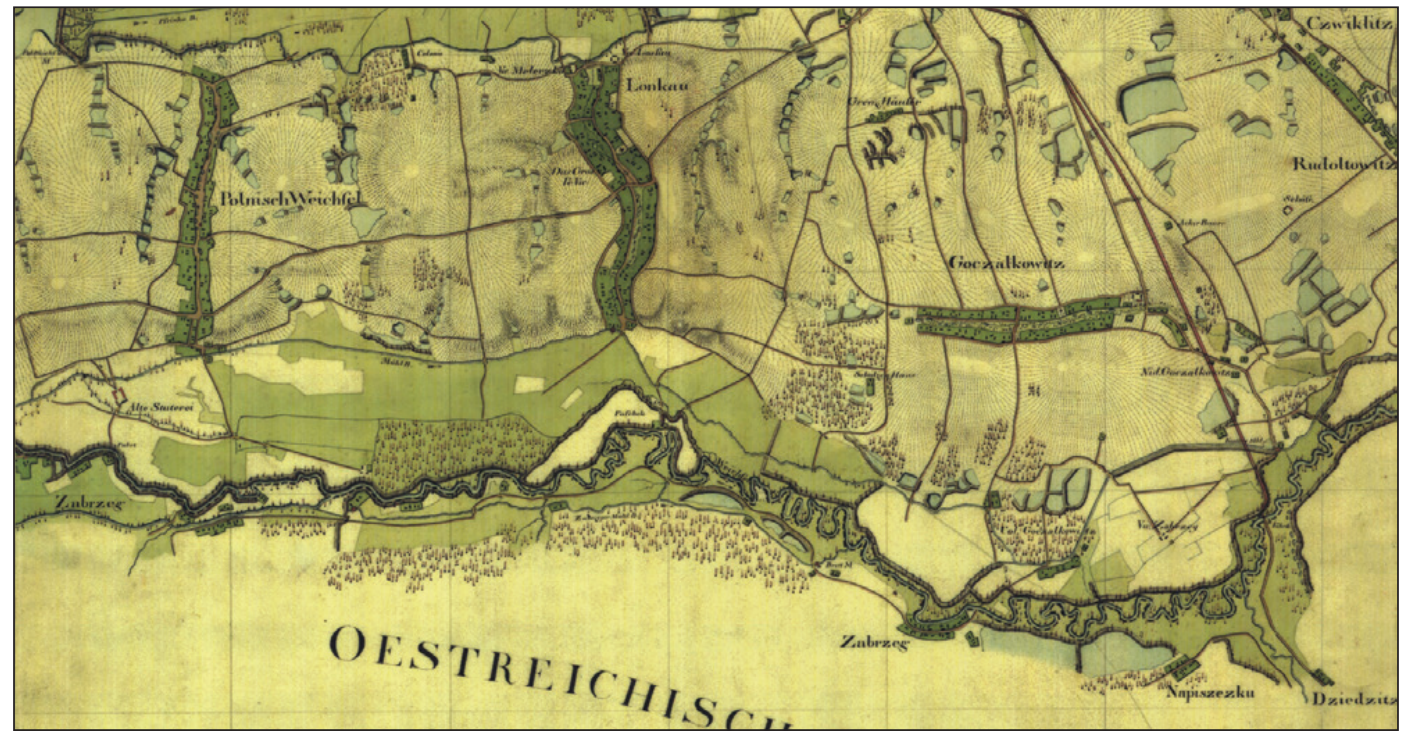

Figure 3. The Mała Wisła Valley between Strumień and the confluence with the Biała on the Urmesstischblätter map dating from 1823-1831.

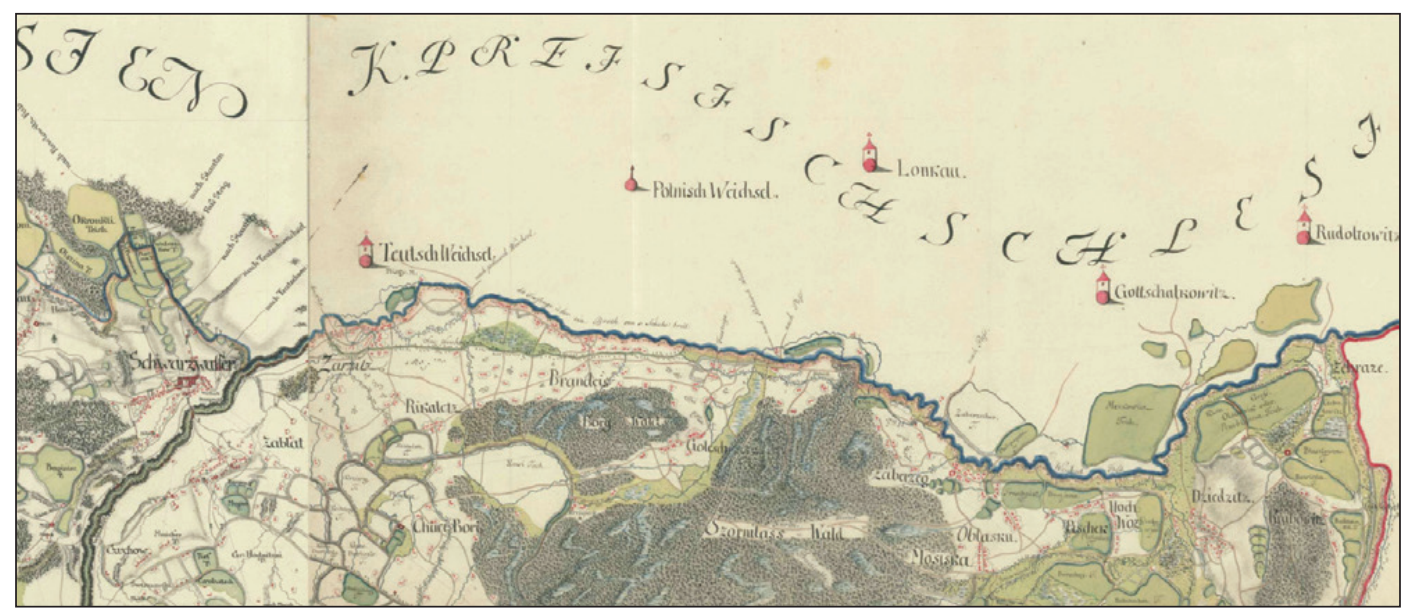

Figure 4. The Mała Wisła Valley between Strumień and the confluence with the Biała on the Kriegs-Charte map dating from 1763-1780.

create oxbow lakes, or else represent dry troughs some 2-3 $\mathrm{m}$ deep. The effect of regulatory work was to lower the erosive base of the river, and hence to encouraging downcutting into the valley floor by even some 1-2 m, as well as the depositing of many elevations that would proved suitable as places to develop settlement. It was on these 'heights' and in the vicinity of stretches of former river channel that large irregularly-shaped multi-road villages came into being. Examples here include Zabrzeg, Zarzecze and Zabłocie, among others (Fig. 4).
Much more suited to the development of rural settlement in the river valley are the valley slopes, the gently-inclined scarps of river terraces and the deposited alluvial flans rising up above the level of the valley floor. The wet and often undulating floodplain of the Valley was not always colonised, while within the part of the Mała Wisła Valley in question the very gentle terrace slopes, alluvial fans and valley sides have not obstructed the development of settlement. It was in fact very common for villages or smaller settlements to be located on even small areas of 
flatter land on slopes or scarps rising just 4-6 m above the floor of the flood terraces. At the same time, the morphological forms in question represented a border zone between land use in the form of meadows and agriculture. The meadow zone occupied the wet valley bottoms, while the high river terraces, valley sides and slightly superficially inundated plateaus were farmed. The founding of settlements at the edge of the farmed land occupying more-elevated areas made the transfer of harvested crops to lower-sited villages easier, along with the pursuit of pastoralism and livestock-rearing based around the valley-bottom meadows. A factor underpinning the sitting of settlements on the sides of the Mała Wisła Valley and the gentle slopes of the river terraces concerned the topoclimatic conditions. The local climate typical of the slopes and sides is far more favourable for people than the valley floor, with its elevated humidity levels.

The flat and wet valley bottoms were also used for centuries as the sites for constructing rearing ponds (like the 'Zabrzeg', 'Maziek', 'Rontok', 'Dębina' and 'Paszek' ponds). Equally, the characteristics of the river channel, as well as the size and shape of the valley and attendant unfavourable hydrological and geomorphological conditions, did not favour the founding of towns - hence the absence of even a single example from the part of the Valley under study.

\section{The shaping of the landscape in the Mała Wisła Valley}

A key role in the shaping of valley bottoms is played by flood events, whose type, magnitude and frequency determine the kind of transport debris is subject to, as well as the length of time over which such transport of material takes place. The stretch of the Mała Wisła under consideration here may be regarded as homogeneous from the hydrological point of view, since no larger tributaries are captured along it.

The river regime is shaped by almost equivalent periods of high water in summer and spring. Nevertheless, flood events are a more frequent occurrence in the summer months, while the rapid flow runoff and uneven flows determine the conditions under which fluvial erosion or accumulation take place. In the area in question, the Vistula channel is flat-bottomed, with a geometry that is shaped by the hydrological regime under description.
The amount by which the river declines in altitude along the length of the Valley is small, while it mainly meanders through loose Quaternary sediments whose thickness ranges between several and several tens of metres.

It was the morphological character of the Vistula Valley between Strumien and the mouth of the River Biała that determined means of management and utilisation. The flat and wide valley bottom provided habitat for meadows and pastures, while - until the end of the 17th century - the Vistula flowed via separate channels between 0.8 and $1.2 \mathrm{~km}$ apart (Fig. 1-6).

Moreover, from the 16th century on, intensive fisheries management based on ponds was carried out, with the effect that a system of bodies of water at times accounting for between 10 and $20 \%$ of the entire valley area took shape. For almost 400 years, therefore, the landscape of this part of the Mała Wisła Valley was dominated by bodies of water separated by earth embankments planted with hedges. Until the mid 20th century, the remaining area of the Valley supported wet meadows with millstreams.

However, the intensive management engaged in the Valley notwithstanding, the landscape here was frequently the subject of change. This reflected flood events whose spread was unlimited by any banks along the channel, ensuring inundation of the Valley area, with attendant destruction of pond embankments and stream-courses alike.

Historical descriptions of floods make it clear that such events have characterised the Vistula Valley from the earliest days, the first mentions dating back to famous chronicler Jan Długosz, who wrote that "In the year 988 there were numerous and protracted overflows (of the Vistula), as followed by a torrid summer that did great harm to many crops" (Girguś \& Strupczewski 1965: 214).

Another description concerns flooding in 1118. "These incessant spills and floods, not only in Poland, but also in neighbouring countries, produced great damage, inundating almost the whole land... Shortly thereafter, there were downpours and storms of such magnitude, with the rivers rising so abruptly, that some feared another flood was beginning..." (Girguś \& Strupczewski 1965: 214).

One of the most major floods along the Vistula Valley in historical times was that of the mid 13th century. "The year 1253 was memorable for Poles on account of a terrible flood the like of which Poland had never before seen. For from Eastertide 


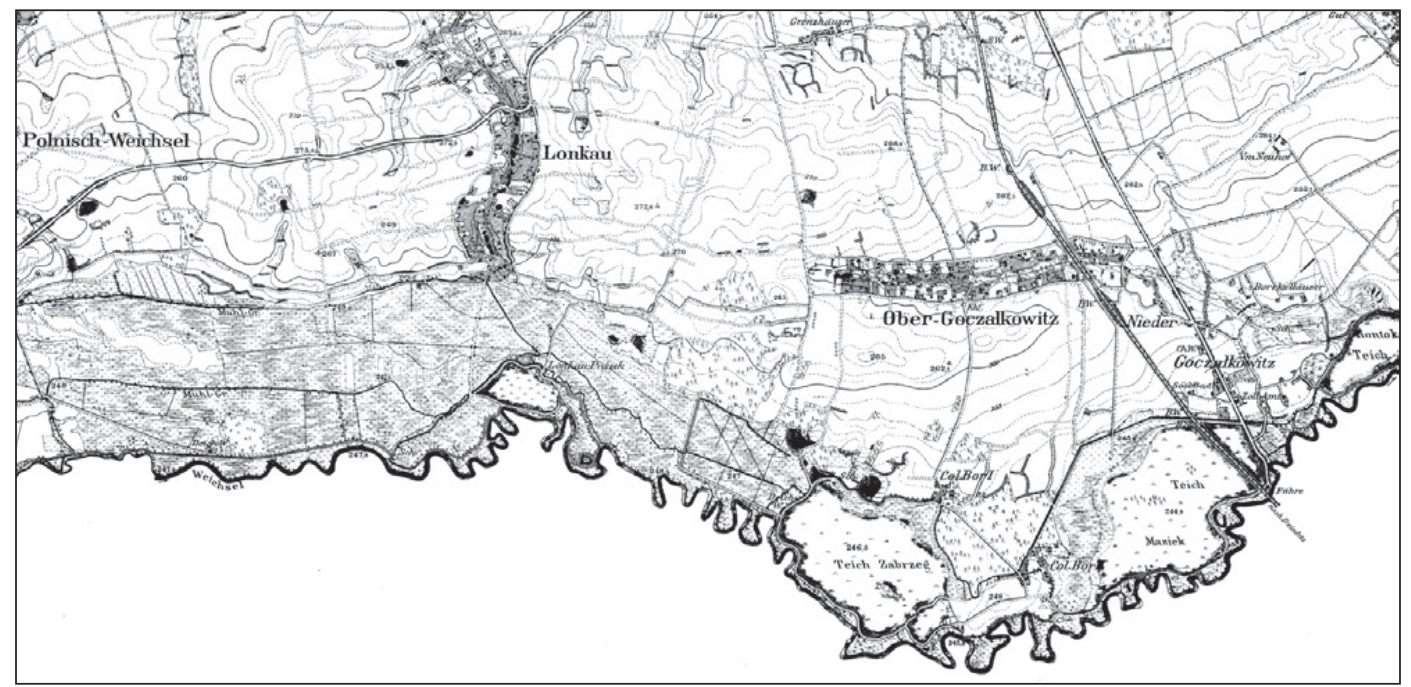

Figure 5. The Mała Wisła Valley between Strumien and the confluence with the Biała on the Messtischblätter map dating from 1881-1884.

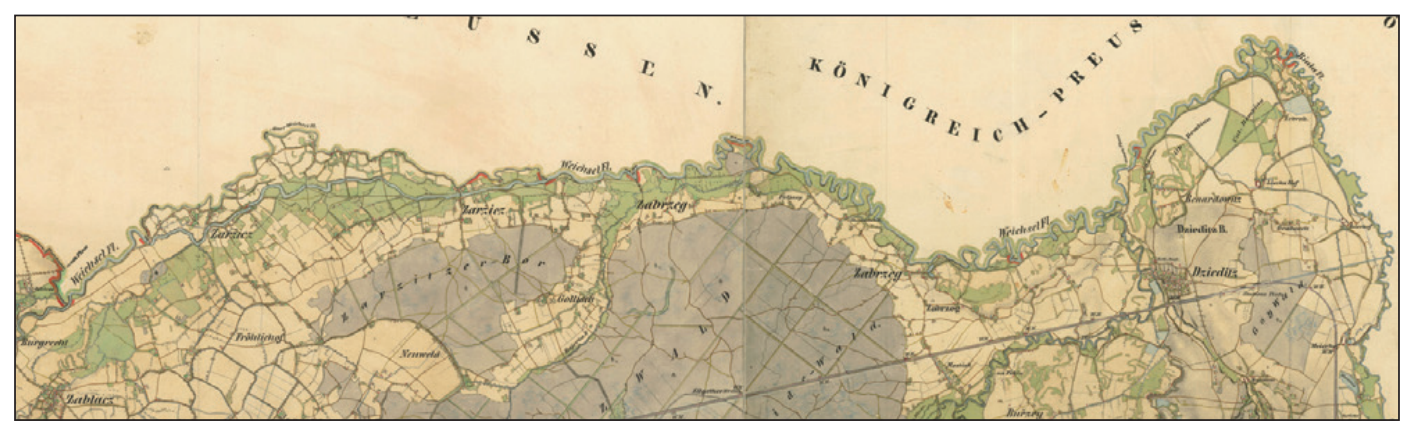

Figure 6. The Mała Wisła Valley between Strumień and the confluence with the Biała on the Übersicht der... map dating from 1861-1863.

through to July 25th rain fell day and night in all the Polish lands. These continuous falls were such as to raise the waters so that boats might sail over fields and dells just as they might on rivers..." (Girguś \& Strupczewski 1965: 214).

Equally major flood events have taken place in the course of the last 200-250 years, and for these events we have much more precise hydrological observations to back up the claims. A series of such floods characterised the years 1772-1775 and 1785-1788, while the worst of all in the 19th century came along in 1813, 1831, 1844 and 1880 (Bielański 1997).

The largest flood of the contemporary era is considered to be that of August 1813. That year in fact brought catastrophic flooding throughout Western and Central Europe, and indeed in many other regions of the world (probably in association with volcanic activity). At the same time, this was not a period favourable to the launching of flood protection measures in the Mała Wisła, Poland being partitioned out of existence over a 123-year period, with the area in question lying in the border area between the Russian and Austrian Empires. On the plus side, the border role played by the Vistula did ensure that numerous large-scale topographic maps of the area under study had been developed by the end of the 18th century. These allow the changes in the landscape to be recreated and analysed, often over rather short intervals.

Maps reveal that flood-damaged ponds would be put back in place rather rapidly, though obviously with different shapes and sizes from what they had had before. The most common trend was for large areas of water to be divided up into 


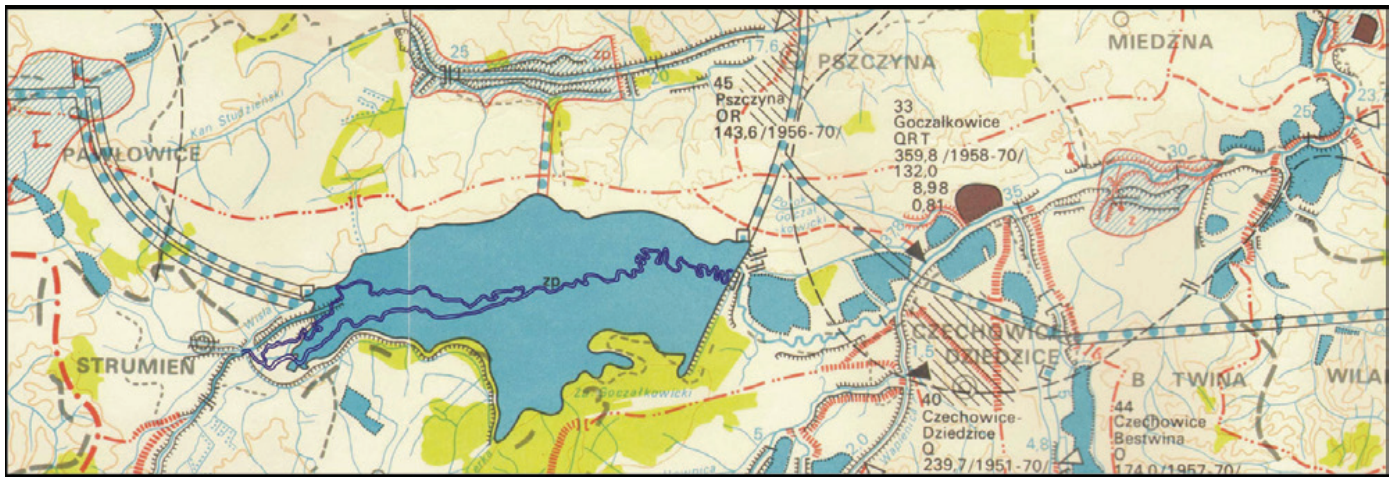

Figure 7. The Mała Wisła Valley between Strumień and the confluence with the Biała on the Mapa Hydrograficzna... dating from 1979 .

smaller ones, while some ponds would be filled in to create new land for crop-growing. There were thus different periods in which ponds accounted for some $8-10 \%$ of the relevant part of the Vistula Valley, or else for as much as $15 \%$.

In the 20th century, there were flood disasters here in the years 1902-1903, 1934 and 1997. The frequent inundation of the Mała Wisła Valley and destruction of infrastructure that they wrought were enough to encourage the initiation of far-reaching regulatory work once Poland had come back into existence in 1918. The work in question was in fact carried out in the years 1926-1929, on the basis of Austrian and Prussian designs elaborated in the 19th century but not put into effect. The river channel in the stretch between Strumien and the mouth of the Biała was in fact shortened by about $5 \mathrm{~km}$, which is to say that regulation reduced its length by almost 25\%.

The second half of the 20th century saw a further marked transformation in the Valley as a result of the construction of the Goczałkowice Reservoir in the years 1953-1955. This reduced the length of the river course yet further, as well as causing the retention of large amounts of river rubble, with the result that erosion below the dam was enhanced (Fig. 7).

The effects of the Valley's inundation by the flood disasters of 1972, 1977, 1997 and 2010 were rather rapidly made good through the restoration of the status quo ante.

\section{Final remarks and conclusions}

The shaping of the landscape within the Mała Wisła Valley in its section between Strumien and the River Biała was such as to condition the means of utilisation and management. Within the Valley, it was the pond-based rearing of fish that prevailed, along with the exploitation of gradients to allow streams to drive watermills and sawmills, as well as facilities for the washing of cloth. The fact that these kinds of uses were made of the Valley - as opposed to other kinds - reflected unfavourable physiographic conditions, these most manifested in the presence of soil that was to moist and heavy to allow cultivation. The threat of flood was applied a further major brake to the development of either agriculture or settlement.

Through analysis of archival sketches and topographic maps from the 18th to 20th centuries, as well as historical records concerning the occurrence of floods and the economic impacts the inundation of the Mała Wisła Valley exerted, it has been possible to note that:

1. through to the mid 20th century, the prevailing means of managing space in the Valley entailed the utilisation of wet meadows in livestock-rearing, as well as fisheries management;

2. large complexes of fishponds long covered some $10-20 \%$ of the entire Valley area;

3. up until the mid 20th century, the sitting of settlements here was dictated by the position of the Valley's flood inundation zone;

4. numerous flood events destroyed hydrotechnical installations, the banks surrounding fishponds, mills and cloth-washing huts. Ponds and millstreams alike were reconstructed after floods, though mostly in changed locations;

5. up until the mid 20th century, an important way in which the land here was utilised involved the exploitation of gradients along streams in the powering of mills, sawmills and cloth-washing facilities; 
6. in the second half of the 20th century, there were major changes wrought in the traditional cultural landscape of the Mała Wisła Valley, as large areas of wet meadows were permanently submerged under the waters of the Goczałkowice Reservoir, whose dam for the

\section{References}

BIELAŃSKI A.K., FISZER J., 1997. Materiały do historii powodzi w dorzeczu górnej Wisły. Na podstawie rękopisu Adama Kazimierza Bielańskiego i materiałów Jana Fiszera. Monografia, ser. Inżynieria Sanitarna i Wodna, no. 217, Kraków: Politechnika Krakowska, $118 \mathrm{pp}$.

CZAKI F.F., CA. 1760. Carte géographique de la Vistule. Sheet no. I, scale ca. 1:180,000, Paris: [s.n. - manuscript].

Czylok A., Szczypek T., Wika S., 1997. Zasoby przyrody żywej w dolinie Wisły między Mętkowem a Rozkochowem (Kotlina Oświęcimska) jako tło dla eksploatacji kruszywa. Sosnowiec-Dąrowa Górnicza: Wydział Nauk o Ziemi Uniwersytetu Śląskiego, Zarząd Zespołu Jurajskich Parków Krajobrazowych Województwa Katowickiego, 66 pp.

GIRGUŚ R., StrupCzeWski W., 1965. Wyjątki ze źródeł historycznych o nadzwyczajnych zjawiskach hydrologiczno-meteorologicznych na ziemiach polskich w wiekach od X do XVI. Warszawa: Wydawnictwa Komunikacji i Łączności, 214 pp.

Kriegs-Charte derer fürstenthümer Teschen, Troppau, JäGERNDORF und NeISSE, SO VON DEM Kays. KÖNIGL. Grossen FelD-General-StaAb aUf AlLerhöChSten BeFEHL ANNO 1763 À LA VUE AUTGENOMMEN WORDEN, 1763-1780. Sectio 1 and 6, Vienna: [s.n. - manuscript].

Mapa Hydrograficzna Systemu Wodno-GospodarczeGO, 1979. Scale 1:100,000, Katowice: Urząd Wojewódzki, Wydział Ochrony Środowiska.

MESSTISCHBLÄTTER, 1881-1884. Sheet no. 3451, scale 1:25,000, Berlin: Königliche Preussische Landesaufnahme. first time limited the risk of flooding downstream.

Editors' note:

Unless otherwise stated, the sources of tables and figures are the author(s), on the basis of their own research.

MichalıK S., 1991. Szata roślinna [in:] I. Dynowska, M. Maciejewski (eds.), Dorzecze górnej Wisły. Część 1. Warszawa-Kraków: Państwowe Wydawnictwo Naukowe, pp. 85-90.

Starkel L., 1991. Rzeźba terenu [in:] I. Dynowska, M. Maciejewski (eds.), Dorzecze górnej Wisły. Część 1. Warszawa-Kraków: Państwowe Wydawnictwo Naukowe, pp. 42-54

Starkel L., 2001. Historia doliny Wisły od ostatniego zlodowacenia do dziś. Monografie, vol. 2, Warszawa: Instytut Geografii i Przestrzennego Zagospodarowania PAN, 263 pp.

SzWEDA G., 2008. Zmiany zagospodarowania przestrzennego i powierzchniowej sieci hydrograficznej $w$ dolinie Wisły na odcinku Zabrzeg - ujście Pszczynki w latach 1830-2008. Sosnowiec: Archive of the Department of Physical Geography, Faculty of Earth Sciences of the Silesian University [typescript].

ÜBERSICHT DER MILITÄR AUfNAHME VON MäHREN UND SCHLESIEN, 1861-1863. Col. XII, sect. 4; col. XIII, sect. 4, scale 1:28,800, Vienna: Militär Akademie zu Viener - Neustadt.

URMESSTISCHBLÄTTER, 1823-1831. Bande X, Blatt 4, scale 1:25,000, Berlin: Königlich Preussischen Generalstabes.

WĘCŁAWIK S., 1991. Budowa geologiczna [in:] I. Dynowska, M. Maciejewski (eds.), Dorzecze górnej Wisły. Część 1. Warszawa-Kraków: Państwowe Wydawnictwo Naukowe, pp. 30-41.

Wieland J.W., 1736. Principatus Silesiae Rattiboriensis nova et exactissima tabula geographica: com [m] onstrans insimul Liberas Dynastias Ples et Beuthen, cum Statu minore Loslau, scale ca. 110,000, Norimbergae: Heredibus Homannianis. 
http://rcin.org.pl 